[Case Report]

\title{
Surgical Treatment for a Ruptured True Posterior Communi- cating Artery Aneurysm Arising on the Fetal-Type Posterior Communicating Artery - Two Case Reports and Review of the Literature -
}

\author{
Yoshiteru Nakano, Takeshi Saito, Junkoh Yamamoto, Mayu Takahashi, Daisuke AkIBA, \\ Takehiro Kitagawa, Ryo Miyaoka, Kunihiro Ueta, Toru Kurokawa and Shigeru NishizaWa \\ Department of Neurosurgery, School of Medicine, University of Occupational and Environmental \\ Health, Japan. Yahatanishi-ku, Kitakyushu 807-8555, Japan
}

\begin{abstract}
Only a small number of aneurysms arising on the posterior communicating artery itself (true Pcom aneurysm) have been reported. We report two cases of ruptured true Pcom aneurysms with some characteristic features of true Pcom aneurysm. A 43 year old man suffering from subarachnoid hemorrhage (SAH) had an aneurysm arising on the fetal-type Pcom artery itself, and underwent surgery for clipping. Most of the aneurysm was buried in the temporal lobe, so retraction of the temporal lobe was mandatory. During the retraction, premature rupture was encountered. After tentative dome clipping and the control of bleeding, complete clipping was achieved. Another patient, a 71 year old woman presenting with consciousness disturbance due to SAH, had an aneurysm on the fetal-type Pcom artery itself, and underwent surgery for clipping. It has been generally considered that hemodynamic factor plays an important role in the formation, the growth, and the rupture of the cerebral aneurysm. This factor is especially significant in true Pcom aneurysm formation and rupture. According to the literature, a combination of fetal type Pcom and formation of the true Pcom aneurysm has been reported in most cases $(81.8 \%)$. Most of the aneurysm can be buried in the temporal lobe, and the retraction of the temporal lobe during the dissection of the neck would be necessary, which causes premature rupture of the true Pcom aneurysm. In the surgery for a true Pcom aneurysm, we should be aware of possible premature rupture when temporal lobe retraction is necessary.
\end{abstract}

Key words : fetal-type posterior communicating artery, hemodynamic stress, subarachnoid hemorrhage, surgical strategy, true posterior communicating artery aneurysm.

(Received September 1, 2011, accepted October 12, 2011) 


\section{Introduction}

Posterior communicating artery (Pcom) is commonly a pair of blood vessels in the circle of Willis. Pcom connects the cerebral arteries. In anterior circulation, it connects to the internal carotid artery (ICA) prior the terminal bifurcation of the ICA into the anterior cerebral artery (ACA) and middle cerebral artery (MCA). In posterior circulation, it connects to the posterior cerebral artery (PCA). Most Pcom aneurysms occur at the divergence of the ICA and Pcom. An aneurysm arising on the Pcom itself is known as a "true" Pcom aneurysm. The definition of the true Pcom aneurysm is an aneurysm that is located at some distance away from the junction of the ICA. A true Pcom aneurysm has rarely been encountered. According to the literature, the reported incidence ranges from 0.1 to $2.8 \%$ of all cerebral aneurysms [1].

We report two patients having a ruptured true Pcom aneurysm, who were successfully surgically treated. We discuss the mechanisms of the formation and growth of true Pcom aneurysm and surgical treatment for such a lesion based on a review of the literature.

\section{Case}

\section{Case 1}

A 43 year old man presented with sudden onset of severe headache after taking a shower. As the severe headache did not subside, the patient visited our hospital on the next day. The patient was hypertensive, but not treated. On admission, the patient was awake and alert, and no neurological deficits were noticed except for neck stiffness.

Computed tomographic scan (CT) on admission showed a Fisher Group 3 subarachnoid hemorrhage (SAH) (Fig. 1). The neurological grade of the patient was classified as Hunt \& Kosnik Grade 2, and World Federation of Neurological Societies Grade I. Cerebral angiograms revealed a saccular aneurysm arising on the fetal type left Pcom itself, distant from the junction of the left ICA (Fig. 2 A, B). A right carotid angiogram showed the fetal type right Pcom and hypoplastic right ACA. A left three-dimensional CT angiogram (3D-CT) also clearly revealed the aneurysm on the fetal type left Pcom and the bleb on aneurysm (Fig. 2 C).

The patient underwent surgery for clipping of the ruptured true Pcom aneurysm via left pterional approach on the admission day. After wide-opening of the sylvian fissure,

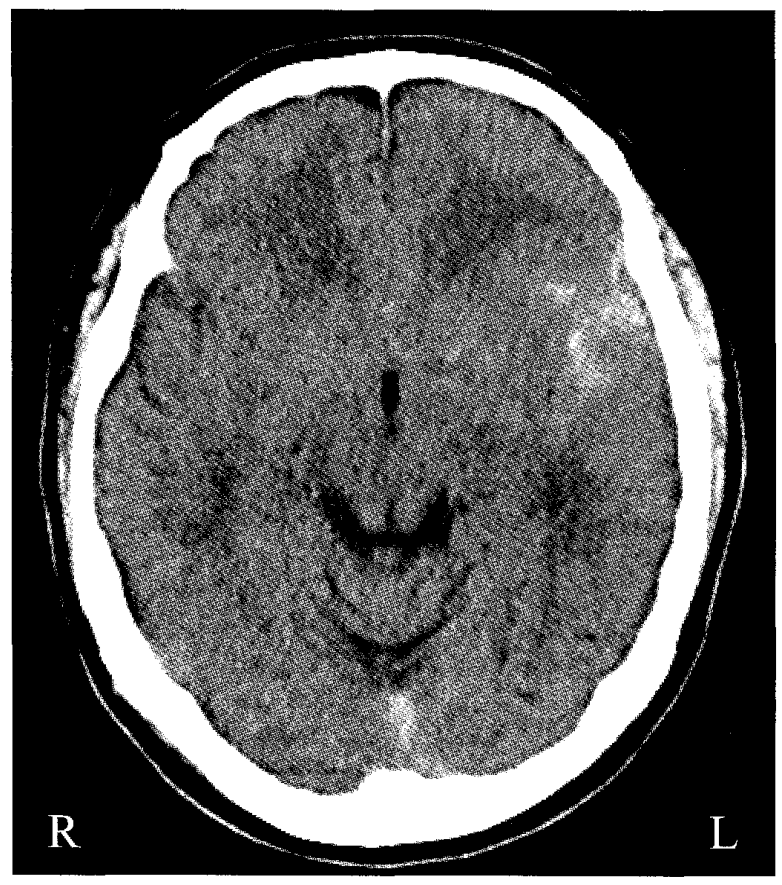

Fig. 1. Computed tomography (CT) of case 1 on admission showing subarachnoid hemorrhage $(\mathrm{SAH})$ in the left sylvian fissure. 


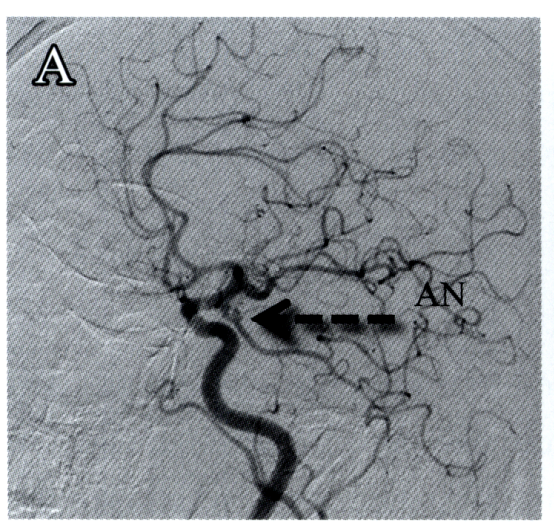

Left carotid angiogram oblique view

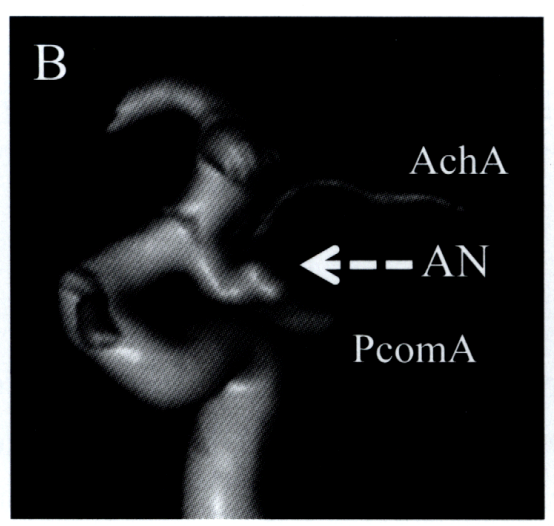

Left 3D-carotid angiogram

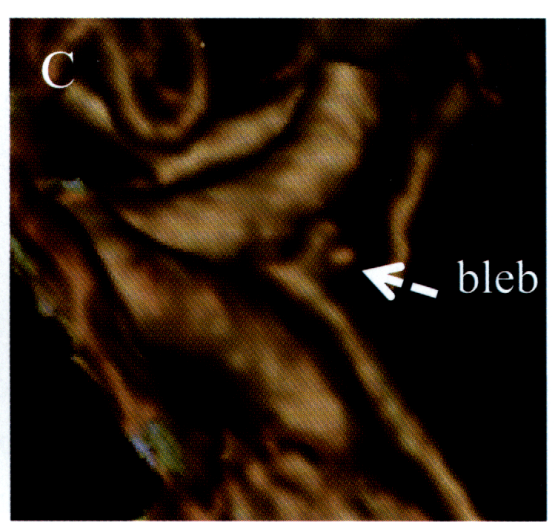

3D-CT angiogram

Fig. 2. Left carotid angiogram and $3 \mathrm{D}-\mathrm{CT}$ angiogram on admission showing an aneurysm on the fetal type left posterior communicating artery (Pcom), distant from the junction of the left internal carotid artery (ICA), and the bleb on the aneurysm dome. Aneurysm size is $2.4 \times 3.5 \times 3.5 \mathrm{~mm}$. AchA: anterior choroidal artery, AN: aneurysm, PcomA: posterior communicating artery.

the left ICA and Pcom were exposed (Fig. 3 A). An aneurysm arising on the distinct fetal Pcom was identified at approximately $2-3 \mathrm{~mm}$ apart from the junction of the left ICA. As most of the aneurysm was buried in the temporal lobe, retraction of the left temporal lobe was necessary for the dissection of the neck. During the retraction of the temporal lobe, premature rupture was encountered (Fig. 3 A). To control the bleeding, a temporary clip was applied to the proximal portion of the fetal type Pcom. Because of fetal type Pcom and backflow, sufficient control of the bleeding from the premature-ruptured aneurysm was not obtained. As the next step, a tentative clip was applied on the dome of the aneurysm. Then, bleeding from the aneurysm was well controlled. Under these conditions, the neck of the aneurysm was meticulously dissected and complete clipping was achieved (Fig. 3 B). The Pcom and perforators were preserved (Fig. 3 B).

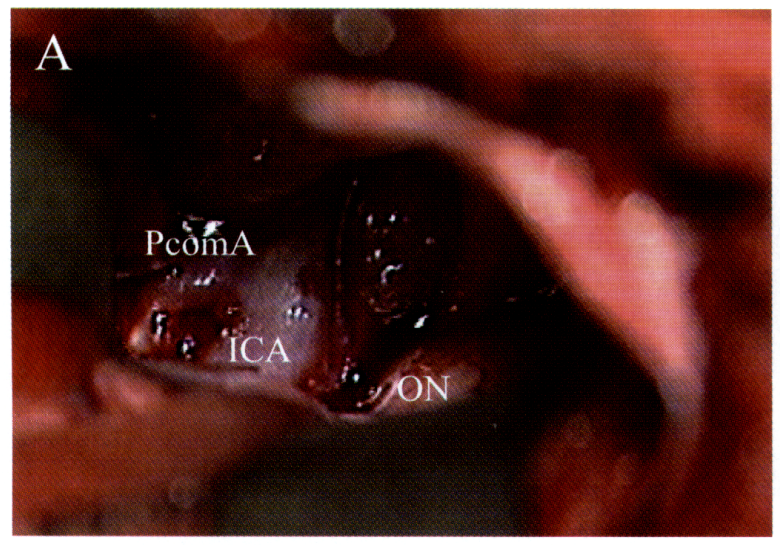

Left pterional approach

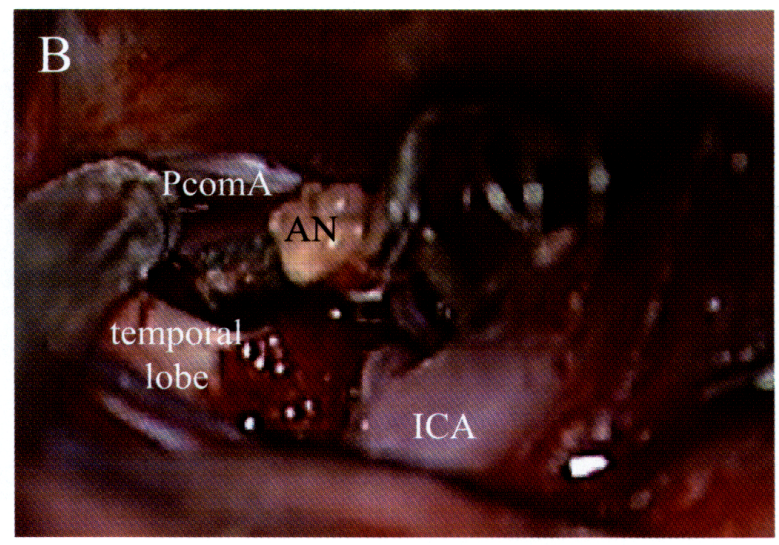

Complete clipping

Fig. 3. Pictures during surgery. AN: aneurysm, ICA: internal carotid artery, ON: optic nerve, PcomA: posterior communicating artery. 
Post-operative CT showed no abnormal low density areas in the perforator-territories. Post-operative cerebral angiogram showed complete obliteration of the true Pcom aneurysm. The post-operative condition of the patient was uneventful, and he was discharged without any neurological deficits three weeks after the surgery.

\section{Case 2}

A 71 year old woman presented with consciousness disturbance at mealtime, so the patient was transfered to our hospital for treatment on the same day. The patient had chronic headache and an old cerebral infarction at the bilateral frontal lobes. On admission, the patient showed consciousness disturbance (JCS10, GCS: E3V4M5) and poor spontaneous movements of the limbs.

CT on admission showed Fisher Group 3 SAH (Fig. 4), and an old cerebral infarction in the bilateral frontal lobe with ACA calcification. The neurological grade of the patient was classified as Hunt \& Kosnik Grade 3, and World Federation of Neurological Societies Grade IV. Cerebral angiograms revealed a vascular dilatation arising on the fetal type right Pcom and showed diffuse vasospasm. Therefore, the patient was treated, at first, with antihypertensive and sedative drugs. On the 14th day after SAH, the second cerebral angiograms revealed a significant saccular aneurysm arising on the fetal type right Pcom itself (Fig. 5). The patient underwent surgery for clipping of the ruptured true Pcom aneurysm via the right pterional approach. Most of the aneurysm was in the temporal lobe, and the right temporal lobe was retracted. During the procedure, a premature rupture was encountered. Under point-suction, the bleeding was controlled and com-

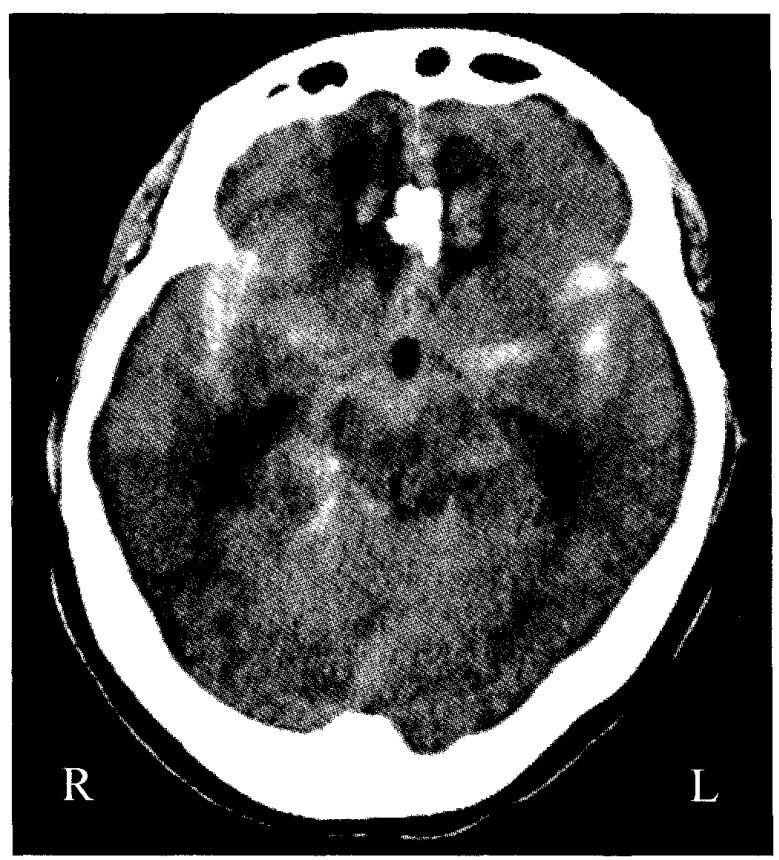

Fig. 4. CT of case 2 on admission showing subarachnoid hemorrhage (SAH) and old cerebral infarction in bilateral frontal lobe and anterior cerebral artery (ACA) calcification. 
plete clipping was achieved. Post-operative CT showed no abnormal low density areas in the perforator-territories. The patient's consciousness disturbance was improving after the surgery, except for mild gait disturbance due to being bedridden for a long time, and she was transferred to the rehabilitation hospital.

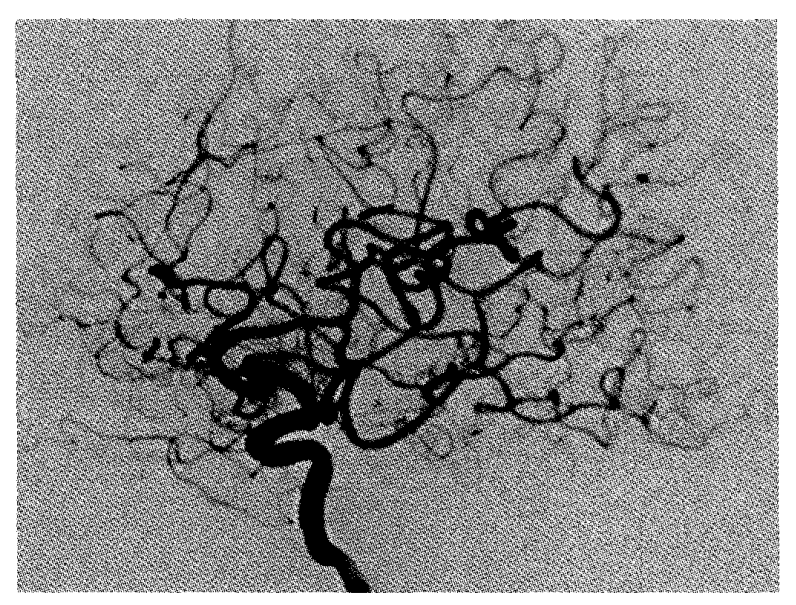

Right carotid angiogram

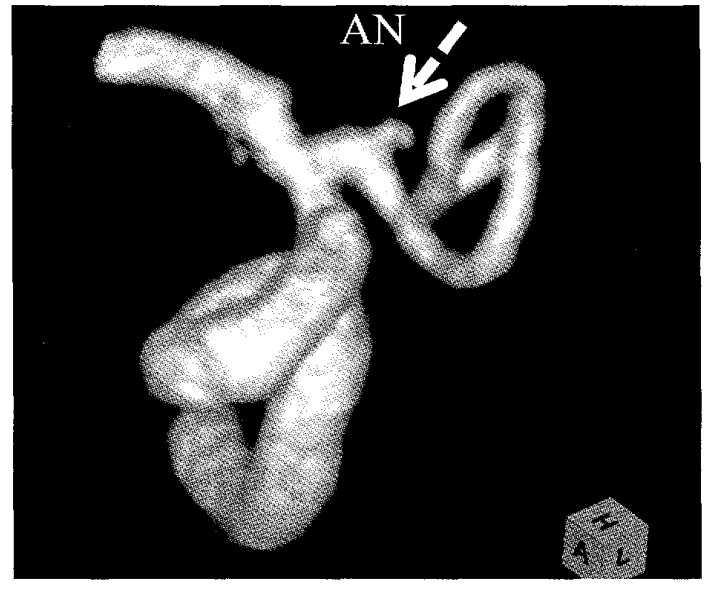

Right 3D-carotid angiogram

Fig. 5. The second right carotid angiogram on the 14th day after subarachnoid hemorrhage (SAH) showing an aneurysm on the fetal type right Pcom, distant from the junction of the right internal carotid artery. AN: aneurysm.

\section{Discussion}

A ruptured true Pcom aneurysm is rarely encountered. According to the literature, the incidence is $0.1-2.8 \%$ of all cerebral aneurysms [1]. Reported cases are listed in Table 1 [2-33].

It has been generally considered that hemodynamic factor plays a significant role in the formation, the growth, and the rupture of cerebral aneurysm. It can be speculated that the same situation as hemodynamic stress significantly influences the true Pcom aneurysm formation, growth, and rupture. The Pcom is classified into three types: normal, hypoplastic and fetal type, by the diameter of the vessel. Fetal type Pcom is approximately $20 \%$ of frequency, and an embryonic derivation of the PCA from the ICA [34]. A fetal type Pcom is thick, and bloodstream is abundant from the ICA. Especially, the existence of fetal type Pcom is important in the mechanisms of the formation and rupture of the true Pcom aneurysm. In the literature, a combination of fetal type Pcom and formation/rupture of the true Pcom aneurysm was reported in most cases (81.8\%) (Table 1). In the present cases, the Pcom of the opposite side was also fetal type. Careful follow-up to identify the formation of true Pcom aneurysm in the opposite side is necessary.

In consideration of surgery, a true Pcom aneurysm is located more distally compared with aneurysms at the junction of internal carotid/posterior communicating arteries. It is more likely that the whole aneurysm or most of the aneurysm is buried in the temporal lobe. For sufficient and meticulous exposure of the aneurismal neck and safe clipping, retraction of the temporal 
Table 1. Summary of reported cases of true Pcom aneurysms

\begin{tabular}{|c|c|c|c|c|c|c|c|c|c|}
\hline No. & Authors (Year) & Age/Sex & SAH & Type & $\begin{array}{l}\text { Pcom fetal } \\
\text { type }\end{array}$ & $\begin{array}{l}\text { Operative } \\
\text { procedure }\end{array}$ & $\begin{array}{l}\text { Premature } \\
\text { rupture }\end{array}$ & Outcome & $\begin{array}{l}\text { References } \\
\end{array}$ \\
\hline 1 & Poppen (1951) & unknown & + & saccular & unknown & trapping & unknown & unknown & 2 \\
\hline 2 & Poppen (1951) & unknown & + & saccular & unknown & trapping & unknown & unknown & 2 \\
\hline 3 & Stuntz et al (1970) & $38 / \mathrm{M}$ & + & saccular & - & unknown & unknown & $\mathrm{D}$ & 3 \\
\hline 4 & Krayenbühl et al (1972) & unknown & + & saccular & unknown & unknown & unknown & unknown & 4 \\
\hline 5 & Krayenbühl et al (1972) & unknown & + & saccular & unknown & unknown & unknown & unknown & 4 \\
\hline 6 & Krayenbühl et al (1972) & unknown & + & fusiform & unknown & unknown & unknown & unknown & 4 \\
\hline 7 & Krayenbühl et al (1972) & unknown & + & fusiform & unknown & unknown & unknown & unknown & 4 \\
\hline 8 & Krayenbühl et al (1972) & unknown & + & fusiform & unknown & unknown & unknown & unknown & 4 \\
\hline 9 & Krayenbühl et al (1972) & unknown & + & fusiform & unknown & unknown & unknown & unknown & 4 \\
\hline 10 & Krayenbühl et al (1972) & unknown & + & fusiform & unknown & unknown & unknown & unknown & 4 \\
\hline 11 & Sano (1978) & unknown & + & unknown & unknown & unknown & unknown & unknown & 5 \\
\hline 12 & Yoshida et al (1979) & $46 / \mathrm{M}$ & + & saccular & - & clipping & - & GR & 6 \\
\hline 13 & Kamiyama et al (1980) & $28 / \mathrm{F}$ & + & saccular & - & trapping & - & GR & 7 \\
\hline 14 & Abiko and Orita (1981) & $57 / \mathrm{F}$ & + & fusiform & + & trapping & - & MD & 8 \\
\hline 15 & Trasi et al (1981) & $26 / \mathrm{F}$ & + & saccular & + & clipping & - & GR & 9 \\
\hline 16 & Tanizaki et al (1982) & $69 / \mathrm{F}$ & + & saccular & + & clipping & - & GR & 10 \\
\hline 17 & Yasargil and Smith (1982) & unknown & unknown & unknown & unknown & unknown & unknown & unknown & 11 \\
\hline 18 & Yasargil and Smith (1982) & unknown & unknown & unknown & unknown & unknown & unknown & unknown & 11 \\
\hline 19 & Yasargil and Smith (1982) & unknown & unknown & unknown & unknown & unknown & unknown & unknown & 11 \\
\hline 20 & Yasargil and Smith (1982) & unknown & unknown & unknown & unknown & unknown & unknown & unknown & 11 \\
\hline 21 & Yasargil and Smith (1982) & unknown & unknown & unknown & unknown & unknown & unknown & unknown & 11 \\
\hline 22 & Yasargil and Smith (1982) & unknown & unknown & unknown & unknown & unknown & unknown & unknown & 11 \\
\hline 23 & Miyazawa et al (1983) & $68 / \mathrm{M}$ & + & saccular & + & clipping & - & GR & 12 \\
\hline 24 & Masuda et al (1984) & $45 / \mathrm{F}$ & + & saccular & + & clipping & - & GR & 13 \\
\hline 25 & Waga et al (1984) & $54 / \mathrm{M}$ & + & saccular & + & clipping & - & GR & 14 \\
\hline 26 & Waga et al (1984) & $64 / \mathrm{M}$ & + & saccular & + & clipping & - & GR & 14 \\
\hline 27 & Takeda et al (1985) & $73 / \mathrm{F}$ & + & saccular & + & clipping & - & $\mathrm{D}$ & 15 \\
\hline 28 & Okada et al (1988) & $40 / F$ & + & saccular & + & clipping & - & GR & 16 \\
\hline 29 & Kudo (1990) & $57 / \mathrm{M}$ & + & saccular & + & clipping & + & GR & 1 \\
\hline 30 & Akimura et al (1991) & $57 / \mathrm{F}$ & + & fusiform & + & trapping & - & MD & 17 \\
\hline 31 & Akimura et al (1991) & $45 / \mathrm{F}$ & + & saccular & + & clipping & - & GR & 17 \\
\hline 32 & Takahashi (1992) & $27 / F$ & + & saccular & + & clipping & - & GR & 18 \\
\hline 33 & Takahashi (1992) & $23 / \mathrm{M}$ & + & saccular & + & clipping & - & GR & 18 \\
\hline 34 & Hayashi (1993) & $51 / \mathrm{M}$ & + & saccular & + & clipping & - & GR & 19 \\
\hline 35 & Kurokawa et al (1993) & $45 / \mathrm{M}$ & + & saccular & + & clipping & - & GR & 20 \\
\hline 36 & Kurokawa et al (1993) & $82 / \mathrm{F}$ & + & fusiform & + & trapping & - & GR & 20 \\
\hline 37 & Kurokawa et al (1993) & $57 / \mathrm{F}$ & + & fusiform & - & trapping & - & MD & 20 \\
\hline 38 & Koga (1994) & $65 / \mathrm{F}$ & + & saccular & + & clipping & - & GR & 21 \\
\hline 39 & Ogasawara (1995) & $58 / \mathrm{F}$ & + & saccular & + & clipping & - & GR & 22 \\
\hline 40 & Timothy et al (1995) & $72 / \mathrm{M}$ & + & fusiform & + & clipping & - & $\mathrm{D}$ & 23 \\
\hline 41 & Matsumoto et al (1997) & $27 / \mathrm{M}$ & + & fusiform & - & clipping & - & MD & 24 \\
\hline 42 & Kawaguchi et al (1998) & $78 / \mathrm{M}$ & - & saccular & + & no surgery & no surgery & $\mathrm{NC}$ & 25 \\
\hline 43 & Okuchi et al (2000) & $66 / \mathrm{M}$ & + & saccular & + & clipping & - & GR & 26 \\
\hline 44 & Muneda et al (2001) & $51 / \mathrm{M}$ & + & saccular & + & clipping & - & GR & 27 \\
\hline 45 & Kaspera et al (2002) & $63 /$ unknown & + & saccular & unknown & clipping & unknown & unknown & 28 \\
\hline 46 & Matsumori et al (2003) & $72 / \mathrm{F}$ & + & saccular & - & clipping & - & GR & 29 \\
\hline 47 & Nakazaki et al (2004) & $51 / \mathrm{F}$ & + & saccular & + & coilingiclipping & - & GR & 30 \\
\hline 48 & Sorimachi et al (2004) & $55 / \mathrm{F}$ & + & saccular & + & clipping & - & $\mathrm{MD}$ & 31 \\
\hline 49 & Freitas et al (2005) & $69 / \mathrm{M}$ & + & unknown & + & endovascular & - & unknown & 32 \\
\hline \multirow[t]{2}{*}{50} & Nakatsuka et al (2007) & $32 / \mathrm{F}$ & + & fusiform & + & trapping & + & GR & 33 \\
\hline & & & & & $\begin{array}{c}81.8 \% \\
(27 / 33)\end{array}$ & & $\begin{array}{l}6.5 \% \\
(2 / 31)\end{array}$ & & \\
\hline
\end{tabular}

GR: good recovery, MD: moderately disabled, NC: no change, D: dead 
lobe is useful. Moreover, it is also true that premature bleeding by retraction of the temporal lobe might tend to occur. Whenever retraction of the temporal lobe is intended, it should be noted that premature rupture could be encountered. According to the literature, premature rupture was reported in two cases (6.5\%) (Table 1). Furthermore, sufficient control of bleeding cannot be obtained only by proximal temporary clip of the fetal type of Pcom because of backflow from the posterior circulation through a distinct fetal Pcom. To control bleeding from a premature rupture, a tentative dome clip is useful. Because of anatomical characteristics, a premature rupture might be caused in surgery for true Pcom aneurysm. It is very important to prepare for premature rupture in true Pcom aneurysmal clipping surgery.

\section{Conclusions}

In the formation, growth, and rupture of a true Pcom aneurysm, hemodynamic stress with the existence of fetal type of posterior communicating artery is important. In the clipping surgery for a true Pcom aneurysm, surgeons should always be prepared for the occurrence of premature rupture when temporal lobe retraction is necessary.

\section{References}

1. Kudo T (1990): An operative complication in a patient with a true posterior communicating artery aneurysm: case report and review of the literature. Neurosurgery 27:650-653

2. Poppen JL (1951): Specific treatment of intracranial aneurysms: Experiences with 143 surgically treated patients. J Neurosurg 8: 75-102

3. Stuntz JT, Ojemann GA \& Alvord EC (1970): Radiographic and histologic demonstration of an aneurysm developing on the infundibulum of the posterior communicating artery: Case report. J Neurosurg 33: 591-595

4. Krayenbühl HA, Yasargil G, Flamm ES \& Tew JM (1972): Microsurgical treatment of intracranial saccular aneurysms. J Neurosurg 37: 678-686

5. Sano K (1978): An introduction of subarachnoid hemorrhage: Focus on treatment of ruptured cerebral aneurysms. Nippon Rinsho 36: 460-466 (in Japanese)

6. Yoshida M, Watanabe M \& Kuramoto S (1979): "True" posterior communicating artery aneurysm. Surg Neurol 11: 379-381

7. Kamiyama K, Sakurai Y \& Suzuki J (1980): Case report: Aneurysm of the posterior communicating artery itself-Report of a successfully treated case. Neurol Med Chir 20: 81-84

8. Abiko S \& Orita T (1981): A case of "true" posterior communicating artery aneurysm. No Shinkei Geka 9: 1181-1185 (in Japanese)

9. Trasi S, Vincent LM \& Zingesser LH (1981): Development of aneurysm from infundibulum of the posterior communicating artery with documentation of prior hemorrhage. Am J Neuroradiol 2: 368-370

10. Tanizaki Y, Kobayashi S, Ichinose Y, Tsuji T \& Sugita K (1982): A case of "true" posterior communicating artery aneurysm with rare intraoperative misclipping. Shinshu Ishi 30: 396-401 (in Japanese)

11. Yasargil MG \& Smith RD (1982): Management of aneurysms of anterior circulation by intracranial 
procedures. In: Neurological Surgery. (Youmans JR, ed). Saunders, Philadelphia pp 1663-1696

12. Miyazawa T, Ishimaru S, Hasegawa T, Watanabe H \& Ishi S (1983): A case of posterior communicating artery aneurysm associated with vascular anomaly of circle of Willis. No Shinkei Geka 11: 541-546 (in Japanese)

13. Masuda T, Uno M \& Matsumoto K (1984): Relatively rare ruptured posterior communicating artery aneurysm: A case report. Geka 46: 1081-1083 (in Japanese)

14. Waga S, Kojima T, Tochio H \& Morikawa A (1984): Aneurysm of the posterior communicating artery itself. Neurol Med Chir 24: 495-498

15. Takeda N, Tamaki N, Asada M, Kurata H \& Matsumoto S (1985): "True" posterior communicating artery aneurysms presenting the abducens nerve palsy. No Shinkei Geka 13: 1331-1334 (in Japanese)

16. Okada T \& Matsuda M (1988): A case of "true" posterior communicating artery aneurysm. Jpn J Stroke 10: 270-274 (in Japanese)

17. Akimura T, Abiko S \& Ito H (1991): True posterior communicating artery aneurysm. Acta Neurol Scand 84: 207-209

18. Takahashi A, Kamiyama H, Imamura H, Kitagawa M \& Abe H (1992): "True" posterior communicating artery aneurysms: report of two cases. Neurol Med Chir 32: 338-341

19. Hayashi T, Sakakibara Y, Yamashita K, Sakamoto T, Ebihara M \& Sekino H (1993): A case of true posterior communicating artery aneurysm. Surg Cereb Stroke 21: 493-496 (in Japanese)

20. Kurokawa Y, Abiko S, Ikeyama Y, Okamura T, Watanabe K, Akimura T \& Ito H (1993) Surgical strategy for "true" posterior communicating artery aneurysm. The MT. Fuji workshop on CVD 11: 93-96 (in Japanese)

21. Koga H, Tsuji T \& Tabuchi K (1994): Clipping of aneurysm arising from the posterior communicating artery itself by contralateral craniotomy: a case report. No Shinkei Geka 22: 553-556 (in Japanese)

22. Ogasawara K, Numagami Y \& Kitahata M (1995): A case of ruptured true posterior communicating artery aneurysm thirteen years after surgical occlusion of the ipsilateral cervical internal carotid artery. No Shinkei Geka 23: 359-363 (in Japanese)

23. Timothy J, Sharr M \& Doshi B (1995): Perils of a 'true' posterior communicating artery aneurysm. Br J Neurosurg 9: 789-791

24. Matsumoto K, Kuriyama M, Tamiya T \& Ohmoto T (1997): Direct clip obliteration of a ruptured giant aneurysm of the posterior communicating artery: case report. Neurosurgery 41: 939-942

25. Kawaguchi S, Noguchi H, Yonezawa T, Hoshida T, Morimoto T \& Sakaki T (1998): Giant true posterior communicating artery aneurysm. J stroke cerebrovasc dis 7: 259-262

26. Okuchi K, Nagata K, Fujioka M, Nishimura F, Nishioka T \& Kagoshima T (2000): Surgical treatment of true posterior communicating artery aneurysm with removal of the anterior clinoid process. Surg Cereb Stroke 28: 142-146

27. Muneda K, Yoshizu H \& Terada H (2001): True posterior communicating artery aneurysm. No Shinkei Geka 29: 163-168 (in Japanese)

28. Kaspera W, Majchrzak H, Kopera M \& Ladzinski P (2002): "True" aneurysm of the posterior communicating artery as a possible effect of collateral circulation in a patient with occlusion of the internal carotid artery. A case study and literature review. Minim Invasive Neurosurg 45: 240-244

29. Matsumori Y, Kayama T, Kokubo Y, Kondo R, Sato S \& Saito S (2003): A case of non-junctional 
posterior communicating artery aneurysm forming kissing aneurysms with an IC-PC aneurysm. Surg Cereb Stroke 31: 365-369 (in Japanese)

30. Nakazaki K, Haga S, Ishidou K, Matsuno H, Ogata N \& Sakata S (2004): Ruptured true posterior communicating artery aneurysm treated by surgical clipping following recanalization after coil embolization: A case report. Japanese J Neurosurg 13: 527-532 (in Japanese)

31. Sorimachi T, Fujii Y \& Nashimoto T (2004): A true posterior communicating artery aneurysm: variations in the relationship between the posterior communicating artery and the oculomotor nerve. $\mathrm{J}$ Neurosurg 100: 353

32. Freitas JM, Pieruccetti MA, Andrade GC, Listik S, Costa RJ, Rodrigues JC Jr, Haikel LF Jr, Gregorini MR \& Pereira CA (2005): High flow "true" posterior communicating artery aneurysm due to hemodynamic effect in a patient with subclavian artery occlusion treated with angioplasty. Arq Neuropsiquatr 63: 693-696

33. Nakatsuka H, Ohta S, Kuroda J, Moriwaki T, Maeda Y \& Sakaki S (2007): Ruptured true posterior communicating artery fusiform aneurysm: case report. No Shinkei Geka 35: 691-696 (in Japanese)

34. van Raamt AF, Mali WP, van Laar PJ \& van der Graaf Y (2006): The fetal variant of the circle of Willis and its influence on the cerebral collateral circulation. Cerebrovasc Dis 22: 217-224 
胎児型後交通動脈から生じた真性後交通動脈瘤破裂症例に対寸る外科的治療

中野 良昭, 齋藤 健, 山本 淳考, 高橋 麻由, 秋葉 大輔, 北川 雄大, 宮岡亮, 植田 邦裕, 黑川暢, 西澤茂

産業医科大学 医学部 脳神経外科学教室

要旨：後交通動脈自体から生じる真性脳動脈瘤は少ないことが知られている．特徵を有す る真性後交通動脈瘤の破裂を生じた 2 症例を文献的な考察を加え報告する。43歳男性, 胎児型後 交通動脈から生じた真性後交通動脈瘤破裂によるくも膜下出血を生じ, 脳動脈瘤クリピング術を 施行した，手術では，脳動脈瘤が側頭葉に埋没していたため, 脳動脈瘤を露出させるには脳の牽引 が必要であった，脳の牽引を行った際に, 脳動脈瘤の術中破裂を生じたため, 仮のクリッピングを 行い, 出血をコントロールし完全な脳動脈瘤クリッピングを行った。71歳女性, 意識障害が出現 し,同様にくも膜下出血を生じ, 脳動脈瘤クリッピング術を施行した，脳動脈瘤の発生，増大, 破裂 には血行力学的な要因が関与すると考えられており,特に真性後交通動脈瘤の発生には重要な要 因となる，文献によると，真性後交通動脈溜は胎児型後交通動脈からの発生が81.8\%とほとんど であった，つまり，胎児型後交通動脈による血行力学的な要因が脳動脈瘤の発生に強く関与して いると考えられる。また, 解剖学的な位置より脳動脈瘤は側頭葉内に埋没していることが多く,脳 動脈瘤クリッピング術の際には脳の牽引が必要となり,術中に脳動脈瘤の破裂を生じる危険性が 高くなる，真性後交通動脈瘤を手術する際には，㐮引時の術中破裂を特に注意し，出血をコント ロールする対応策を備えておくべきである。

キーワード: 胎児型後交通動脈, 血行力学的ストレス, くも膜下出血, 外科的治療, 真性後交通動脈瘤.

J UOEH（産業医大誌）33（4）：303-312（2011） 